\title{
Natural Products: Perspectives and Challenges for use of Brazilian Plant Species in the Bioeconomy
}

\author{
MARILIA VALLI and VANDERLAN S. BOLZANI \\ Nuclei of Bioassays, Biosynthesis and Ecophysiology of Natural Products (NuBBE), Department of Organic Chemistry, \\ Institute of Chemistry, São Paulo State University (UNESP), Av. Prof. Francisco Degni, 55, 14800-900 Araraquara, SP, Brazil
}

Manuscript received on February 20, 2019; accepted for publication on April 15, 2019

\begin{abstract}
How to cite: VALLI M AND BOLZANI VS. 2019. Natural Products: Development, Perspectives and Challenges for the Brazilian Plant Species and the Bioeconomy. An Acad Bras Cienc 91: e20190208. DOI 10.1590/00013765201920190208 .

Abstract: The development of our society has been based on the use of biodiversity, especially for nutrition, medicines and beauty. Brazil is the nation with the largest biodiversity in the world, with a rich chemical diversity, which is a potential source for bioeconomy. Considering the chemical and biological diversity of the Brazilian territory, we would like to highlight the value of secondary metabolites from Brazilian biodiversity with potential application for new products and technologies and the importance of scientific programs to support the sustainable use of biodiversity.
\end{abstract}

Key words: Brazilian biodiversity, natural products, database, medicinal chemistry.

\section{INTRODUCTION}

Biodiversity has been the basis for the development and growth of our society. Plant species, were essential for human survival, particularly those having nutrition and medicinal uses. Ancient populations around the planet established a set of useful plant species by a long experienced selection. According to the World Health Organization, the use of traditional medicine is growing in developed countries as a complimentary use and reaches $80 \%$ in Africa, that depends essentially on plants for primary health care (WHO 2017). Pharmaceutical companies are interested in investigating plants as source for new lead structures and also for the

Correspondence to: Vanderlan da Silva Bolzani

E-mail: bolzaniv@iq.unesp.br

ORCid: https://orcid.org/0000-0001-7019-5825 development of standardized herbal agents with proved efficacy, safety and quality (Calixto 2000). The medicinal properties of plants have been the focus of scientific researches in the field of natural products, and great advances were achieved in the last centuries (Valli et al. 2012). The determination of the molecular structure of morphine was the first documented structural elucidation, and since then many natural products medicines or synthetic derived were launched. A glance in the past has shown that the traditional knowledge was the basis of some of the most important medicines that changed the history of humankind health, Figure 1. Nature continues to be extraordinarily generous in providing the most sophisticated natural products, with an incredible variety of complicated structures, so far, very important as models for the production 


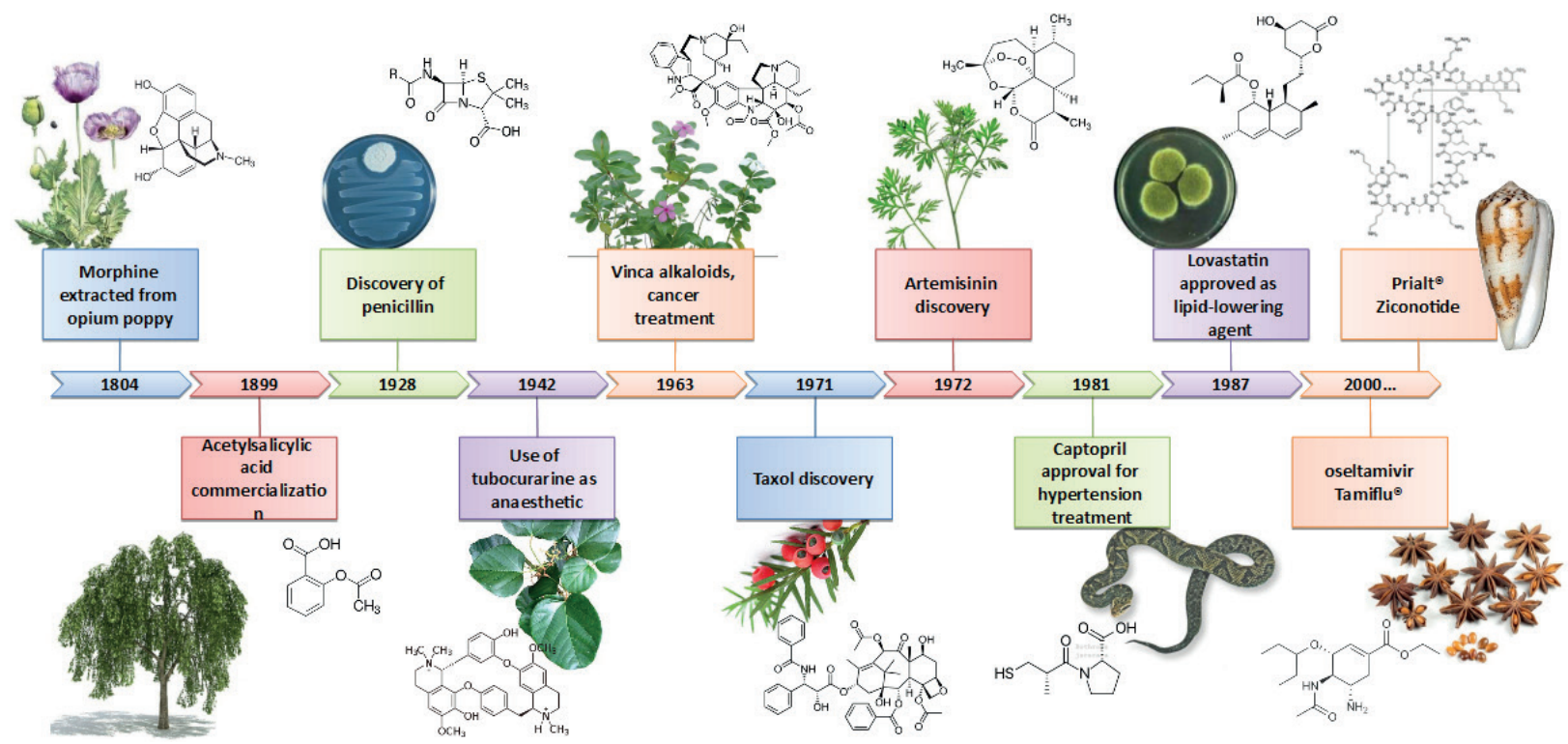

Figure 1 - A few natural products used as medicines identified in the last century.

of medicine, cosmetics, food supplements, and other bioproducts.

Given the number of plant species on Earth and the several biosynthetic pathways capable of producing extraordinary chemical diversity, biodiversity in tropical and equatorial environments offers a particularly rich potential in biologically active compounds that can be used as models for medicinal chemistry and drug discovery (Bolzani et al. 2012). The biosynthetic pathways of several classes of secondary metabolites in plants species may afford many kind of natural products such as lignans, flavonoids, terpenes, alkaloids, etc (Figure 2).

The term biodiversity can be defined as the variety and complexity among living organisms, encompassing species, DNA, genes, proteome, metabolome and their interaction with their ecological systems (Wilson 1999, Noss 1990). Associated with biodiversity, there is a rich diversity of natural compounds with peculiar structures that are still one of the most sophisticated sources of new molecular models for medicinal chemistry, development of new drugs, agrochemicals, fragrances, cosmetics, and food supplements. Among the 1211 new low molecular weight prototypes (known as New Chemical Entities - NCE) introduced on the world market as pharmaceuticals during the period 1981-2014, 60\% are derived from natural products, mimetics or designed from natural product structures (Newman and Cragg 2016).

Brazil is the country with the largest biodiversity in the world and has been taking actions to preserve it, being the first nation to sign the Convention on Biological Diversity in 1992. (MMA 2017). Brazil has an area of $8,511,996 \mathrm{~km}^{2}$ in which six terrestrial biomes are distributed (the Amazon rainforest, the Caatinga, the savana-like Cerrado, the Atlantic Forest, the swamp known as the Pantanal and the Pampas) and a sea coast of 7,491 km hosting three marine ecosystems and twelve major hydrographic regions (Figure 3, MMA 2017). Two of these ecosystems, the Atlantic Forest and the Cerrado, are considered hotspots of biodiversity due to the accelerated loss of biological diversity caused by urbanization, agriculture and livestock. (MMA 2017, Myers et al. 2000).

Bioeconomy is not a business segment or a specific scientific innovation but includes "all 


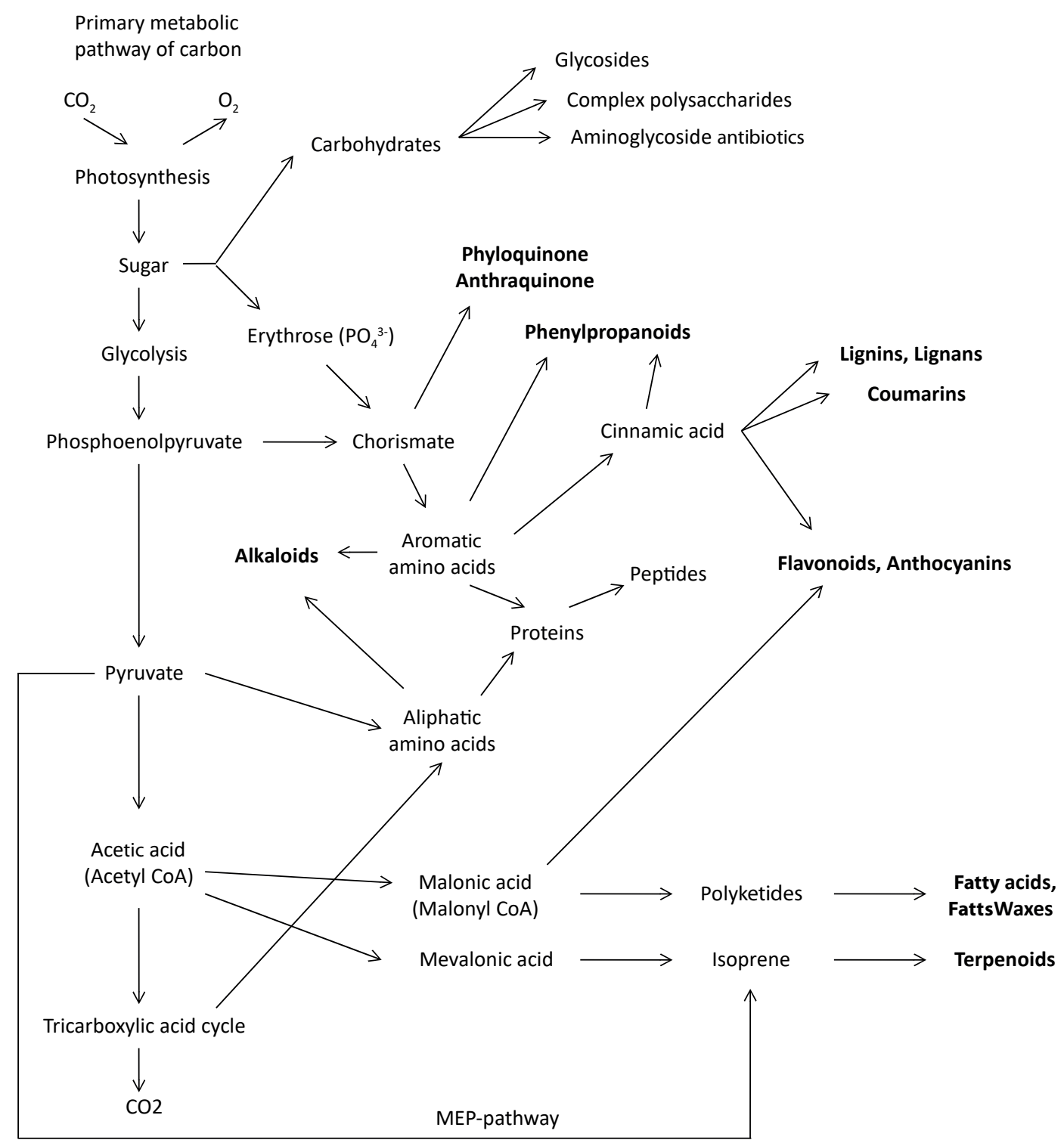

Nugroho, L. H.; Verpoorte, R. Secondary metabolism in tobacco. Plant Cell, Tissue and Organ Culture, 68:105-125, 2004

Figure 2 - Biosynthetic pathways of plants (adapted from Nugroho and Verpoorte 2004).

economic activity derived from bio-based products and processes which contribute to sustainable and resource-efficient solutions to the challenges we face regarding food, chemicals, materials, energy production, health and environmental protection" (RSB 2017). Bioeconomy is now part of the strategic actions of more than 40 countries (El Chichakli et al. 2016). It uses bio-based products, commodities and electricity, instead of fossil-based ones. Bioeconomy is the key element that could address some of the important challenges faced by society, especially regarding energy generation by replacing non-green fossil fuels with cleaner alternatives (Philp 2015). It comes to assist the replacing and changing the world's economical systematic in order to prevent collapse. We could take metabolic engineering as an example of new technologies that had considerably broadened the 


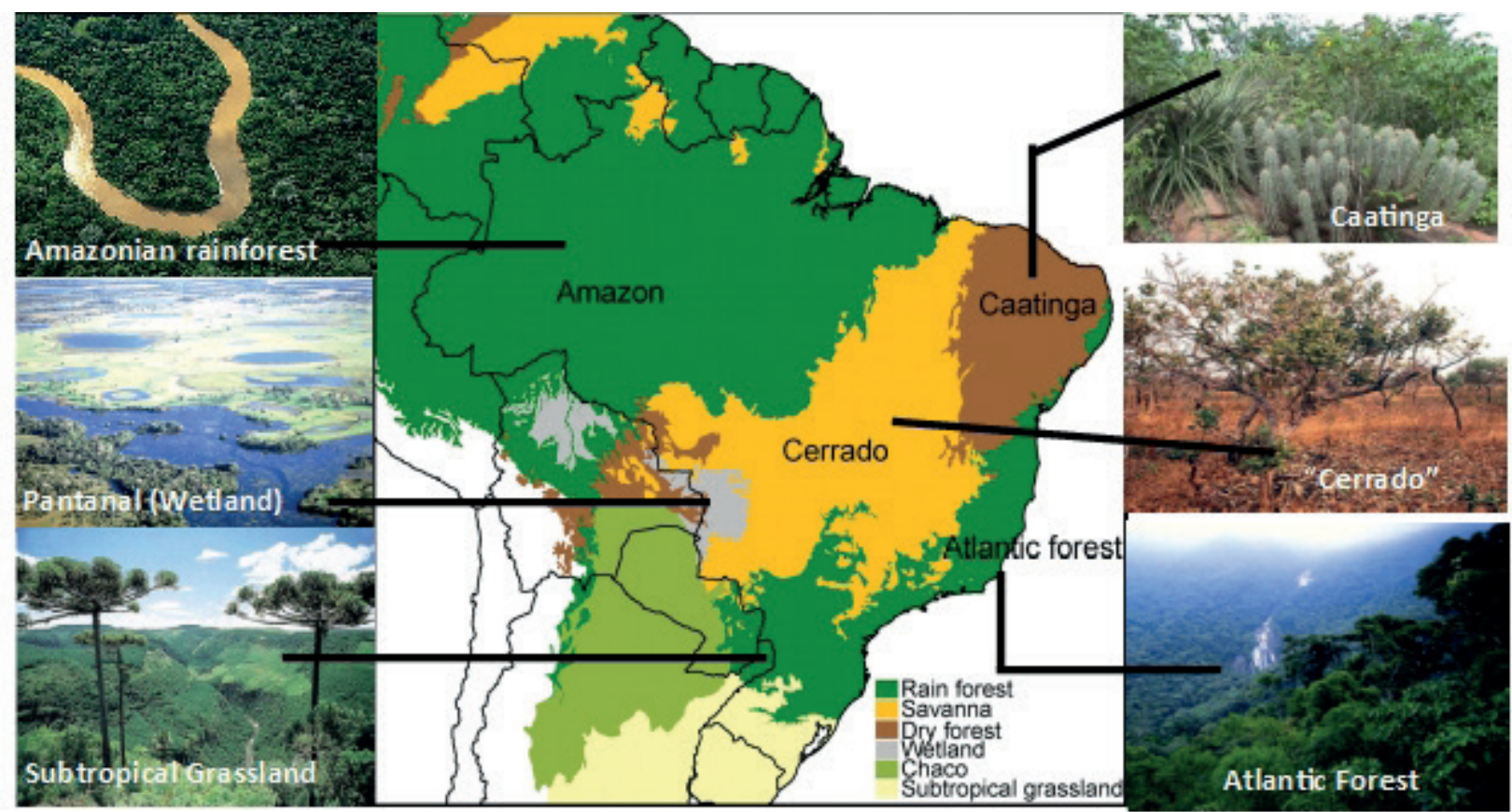

Figura 3 - Six Brazilian terrestrial biomes: Amazon rainforest, Caatinga, the savana-like Cerrado, Atlantic Forest, the grasslands Pampas, and the wetlands known as the Pantanal.

variety and number of compounds now accessible that were once restricted to naturally occurring metabolites (Murphy 2011).

Brazil could be a leader in this economic transition since it is granted with all the conditions to be a sustainable model. It has the largest biodiversity of the globe, suitable climate condition, abundant land, relative small population and plenty of natural resources. Infrastructure has to be improved and greener technologies must be incorporated to industry and agriculture. Brazilian economic success heavily relied on commodity exports. This commodity success deviated attention from important actions that should have been done in structural (infrastructure, political reforms) and institutional (education, research, institutes) investments. Brazil failed in converting its economic boom into knowledge, as can be seen by the global share of high added value export that scarcely changed in the last 20 years (Gallagher and Porzecanski 2010). Brazil should now "run after the lost time" and heavily invest in turning commodities to high added value products.
That means investing evenly in education, science and innovative industry. Maybe more important than investment, Brazil should focus on improving public management and supporting innovation by reducing bureaucracy. As an example, patent application in Brazil expects to wait 11 years to be approved, but this has started to be addressed (INPI 2017).

Considering the chemical and biological diversity present in Brazil, there is a universe of opportunities for bio-based innovation. There are a few Brazilian natural products that were successfully used to develop new products and give evidence of the country biodiversity potential. Brazilian biodiversity is undoubtedly vast. Nevertheless, few products have emerged from this rich chemical universe.

The discovery of bradykinin (1) (Figure 4), isolated from the venom of Bothrops jararaca, is one of these examples (Ferreira et al. 1970). This peptide is an inhibitor of the angiotensinconverting enzyme (ACE), which is responsible for the conversion of angiotensin I to angiotensin 
<smiles>CC(CS)C(=O)N1CCC[C@H]1C(=O)O</smiles>

Figure 4 - Bradykinin (1), a peptide extracted from Bothrops jararaca and the drug captopril (2, Captoten $($ ) an ACE inhibitor used for the treatment of hypertension designed from molecular simplification of $\mathbf{1}$..

II during the passage through the pulmonary circulation, and an important target for hypertension treatment. Further investigations and structural simplification led to the development of a new class of peptidomimetics, the ACE inhibitors, classically represented by captopril (2), $\left(\right.$ Captoten $\left.^{\circledR}\right)$ (Figure 4; Buss and Waigh 1995).

Concerning drug development, there are no examples of pure drug compounds developed as drugs in Brazil, however, there are some herbal medicines developed completely in Brazil. Natural products from the Brazilian biodiversity have been extensively studied in research groups in Brazil, but the great number of isolated compounds is not consistent with the very few examples of drugs developed. The first drug based on a chemically standardized extract of Cordia verbenaceae (Borraginaceae) was launched a few years ago on the pharmaceutical market as Acheflan $^{\circledR}$ (Achē). This topical anti-inflammatory drug was completely developed in Brazil and consists of a mixture of sesquiterpenes of the essential oil of C. verbenaceae (Passos et al. 2007, Fernandes et al. 2007). The pharmaceutical industry Achē also launched the anxiolytic standardized herbal medicine Sintocalmy ${ }^{\circledR}$ prepared with the extract of Passiflora incarnata (Passifloraceae) containing the flavonoid vitexin (apigenin-8-C-glucoside) (3) (Figure 5) as one of the active compounds. Besides that, Stryphnodendron adstringens (Mart.) is traditionally used in wound healing, and the<smiles>O=c1cc(-c2ccc(O)cc2)oc2c(C3O[C@H](CO)[C@@H](O)[C@H](O)[C@H]3O)c(O)cc(O)c12</smiles>

Figure 5 - The flavonoid vitexin (3), from the Passiflora incarnata extract, one of the compounds present in the herbal medicine Sintocalmy ${ }^{\circledR}$

pharmaceutical company Apsen Farmacêutica have developed Fitoscar ${ }^{\mathbb{R}}$, an ointment based on this species that contain a mixture of phenolic derivatives, mainly condensed tannins (Souza et al. 2007, Minatel et al. 2010).

Recent work on Brazilian fruits has led to the isolationofseveralphenolics from Spondiastuberosa (Anacardiaceae), by a combination of HPLCUV-MS, HPLC-microfractionation, followed by biological assays aimed at the localization of the active compounds. An efficient isolation procedure was performed on the $\mathrm{MeOH}$ extract using a gradient transfer of analytical HPLC conditions to the preparative MPLC-UV separation. This method afforded the isolation of seven compounds, including two new natural products. Compounds 4 and 5 (Figure 6) presented high antioxidant activity and acetylcholinesterase inhibition. This data was 
published (Zeraik et al. 2016) and a patented was issued (WO2016058070A1), which is in agreement with a Germany Company for possible development of a product.

Another recent program for biodiversity is the NuBBE database: the database of natural products from Brazilian biodiversity. The chemical diversity of the Brazilian species is being catalogued by this project created in 2013, initially with 640 compounds isolated and identified by the Research Group Nucleus of Bioassay, Biosynthesis and Ecophysiology of Natural Products (Valli et al. 2013). NuBBE ${ }_{D B}$ currently provides data of more than 2000 compounds of plants, marine organisms, fungi, etc, and contains chemical (metabolic class, chemical structure, physicochemical properties, common and IUPAC name and molecular mass), biological (occurrence, habitat, biological activities), pharmacological and spectroscopic data (Pilon et al. 2017). This database is freely accessible online, where it is possible to search for properties, chemical structure, class of natural products or a combination of molecular or biological criteria (NUBBEDB 2017).

The scientific information published in more than 50 years of studies on Brazilian biodiversity becomes easier to access when standardized, certified and organized in a database. The access and mapping of the molecular heritage of Brazilian biodiversity significantly reduces the time spent in understanding and increases feasibility of applying processes that involve technological research. This information center is freely available online in order to bring benefits both to science and to strengthen the national bioeconomy. Countries like Germany and England have a robust bioeconomy although they do not have a great biodiversity in their territories. In this sense, the objective of $\mathrm{NuBBE}_{\mathrm{DB}}$ is to assist in the development of different fields of Brazilian science, technological development of biodiversity products with high added value and public policies. The $\mathrm{NuBBE}_{\mathrm{DB}}$ is being used by
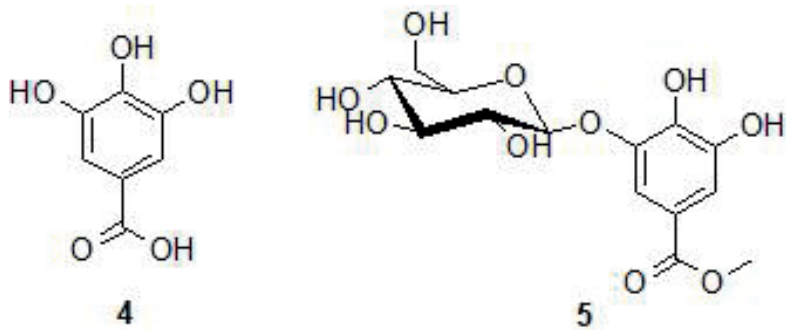

Figure 6 - Gallic acid (4) and derivative (5), isolated from the pulp of Spondias tuberosa, presented high antioxidant activity and acetylcholinesterase inhibition.

the scientific community (Villoutreix et al. 2013, Harvey et al. 2015, Kuenemann et al. 2016, Neves et al. 2015, Mohamed et al. 2016),

\section{ACKNOWLEDGMENTS}

The authors acknowledge Fundação de Amparo à Pesquisa do Estado de São Paulo (FAPESP) grants \#2013/07600-3 (CIBFarCEPID), \#2014/50926-0 (INCT BioNat CNPq/ FAPESP), BIOTA-FAPESP grant \#2003/02176-7, SISBIOTA-CNPq-FAPESP grant \#2010/523275, Coordenação de Aperfeiçoamento de Pessoal de Nível Superior (CAPES), Conselho Nacional de Desenvolvimento Científico e Tecnológico (CNPq) grant \#465637/2014-0 and Termo de Execução Descentralizado Arbocontrol \#74/2016 for grant support and research fellowships. Authors acknowledge scholarships: MV (CNPQ \#167874/2014-4 and \#152243/2016-0; Finatec \#120/2017).

\section{AUTHOR CONTRIBUTIONS}

Both authors MV and VSB contributed in writing, revision and design of figures.

\section{REFERENCES}

BOLZANI VS, VALLI M, PIVATTO M AND VIEGAS JR C. 2012. Natural products from Brazilian biodiversity as a source of new models for medicinal chemistry. Pure Appl Chem 84: 1837-1846.

BUSS AD AND WAIGH RD. 1995. Natural products as leads for new pharmaceuticals. In: Wolff ME (Ed), Burger's medicinal chemistry and drug discovery. Principles and 
practice. Vol. 1. John Wiley \& Sons, Inc; New York, NY. p. $983-1033$.

CALIXTO JB. 2000. Efficacy, safety, quality control, marketing and regulatory guidelines for herbal medicines (phytotherapeutic agents). Braz J Med Biol Res 33: 179-189.

EL-CHICHAKLI B, VON BRAUN J, LANG C, BARBEN D AND PHILP J. 2016. Five cornerstones of a global bioeconomy. Nature 53: 221-223.

FERNANDES ES, PASSOS GF, MEDEIROS R, CUNHA FM, FERREIRA J, CAMPOS MM, PIANOWSKI LF AND CALIXTO JB. 2007. Anti-inflammatory effects of compounds alpha-humulene and (-)-trans-caryophyllene isolated from the essential oil of Cordia verbenacea. Eur J Pharmacol 569: 228-236.

FERREIRA SH, BARTELT DC AND GREENE LJ. 1970. Isolation of bradykinin-potentiating peptides from Bothrops jararaca venom. Biochem 9: 2583-2593.

GALLAGHER KP AND PORZECANSKI R. 2010. The Dragon in the Room: China and the Future of Latin American Industrialization. Stanford University Press, $198 \mathrm{p}$.

HARVEY AL, EDRADA-EBEL RA AND QUINN RJ. 2015. The re-emergence of natural products for drug discovery in the genomics era. Nature 14: 111-129.

INPI - INSTITUTO NACIONAL DE PROPRIEDADE INDUSTRIAL. 2017. Available at: http://www.inpi.gov. $\mathrm{br} /$ sobre/planejamento.

KUENEMANN MA, LABBÉ CM, CERDAN AH AND SPERANDIO O. 2016. Imbalance in chemical space: how to facilitate the identification of protein-protein interaction inhibitors. Sci Rep 6: 23815.

MINATEL DG, PEREIRA AMS, CHIARATTI TM, PASQUALIN L, OLIVEIRA JCN, COUTO LB, LIA RCC, CINTRA JM, BEZZON MFA AND FRANCA SC. 2010. Estudo clínico para validação da eficácia de pomada contendo barbatimão (Stryphnodendron adstringens ( Mart.) Coville)* na cicatrização de úlceras de decúbito. Rev Bras Med 67: 250-256.

MMA - MINISTÉRIO DO MEIO AMBIENTE. 2017. Available at: www.mma.gov.br/portalbio.

MOHAMED A, NGUYEN CH AND MAMITSUKA H. 2016. Current status and prospects of computational resources for natural product dereplication: a review. Brief Bioinform 17: 309-321

MURPHY AC. 2011. Metabolic engineering is key to a sustainable chemical industry. Nat Prod Rep 28: 14061425.

MYERS N, MITTERMELER RA, MITTERMELER CG, FONSECA GAB AND KENT J. 2000. Biodiversity hotspots for conservation priorities. Nature 403: 853-858.

NEVES BJ, ANDRADE CH AND CRAVO PVL. 2015. Natural products as leads in schistosome drug discovery. Molecules 20: 1872-1903.

NEWMAN DJ AND CRAGG GM. 2016. Natural Products as Sources of New Drugs from 1981 to 2014. J Nat Prod 79: 629-661.
NOSS RF. 1990. Indicators for Monitoring Biodiversity: A Hierarchical Approach. Conserv Biol 4: 355-364.

NUBBEDB. 2017. NuBBE database. Available at: http:// nubbe.iq.unesp.br/nubbeDB.html.

NUGROHO LH AND VERPOORTE R. 2004. Secondary metabolism in tobacco. Plant Cell Tissue Organ Cult 68: 105-125.

PASSOS GF, FERNANDES ES, CUNHA FM, FERREIRA J, PIANOWSKI LF, CAMPOS MM AND CALIXTO JB. 2007. Anti-inflammatory and anti-allergic properties of the essential oil and active compounds from Cordia verbenacea. J Ethnopharmacol 110: 323-333.

PHILP J. 2015. Balancing the bioeconomy: supporting biofuels and bio-based materials in public policy. Energy Environ Sci 8: 3063-3068.

PILON AC, VALLI M, DAMETO AC, PINTO MEF, FREIRE RT, CASTRO-GAMBOA I, ANDRICOPULO AD AND BOLZANI VS. 2017. $\mathrm{NuBBE}_{\mathrm{DB}}$ : an updated database to uncover chemical and biological information from Brazilian biodiversity. Sci Rep 7: 7215.

RSB - ROYAL SOCIETY OF BIOLOGY. 2017. Available at: https://www.rsb.org.uk/images/RSB_response_to_the BEIS_Bioeconomy_consultation_Final_response.pdf.

SOUZA TM, MOREIRA RRD, PIETRO RCLR AND ISAAC VLB. 2007. Avaliação da atividade anti-séptica de extrato seco de Stryphnodendron adstringens (Mart.) Coville e de preparação cosmética contendo este extrato. Rev Bras Farmacogn 17: 71-75.

VALLI M, PIVATTO M, DANUELLO A, SILVA DHS, CASTRO-GAMBOA I, CAVALHEIRO AJ, ARAÚJO AR, FURLAN M, LOPES MN AND BOLZANI VS. 2012. The Tropical Biodiversity: has it been a potential source of secondary metabolites useful for medicinal chemistry? Química Nova 35: 2278-2287.

VALLI M, SANTOS RN, FIGUEIRA LD, NAKAJIMA CH, ANDRICOPULO AD AND BOLZANI VS. 2013. Development of a natural products database from the biodiversity of Brazil. J Nat Prod 76: 439-444.

VILLOUTREIX BO, LAGORCE D, LABBÉ CM, SPERANDIO O AND MITEVA MA. 2013. One hundred thousand mouse clicks down the road: selected online resources supporting drug discovery collected over a decade. Drug Disc Today 18: 1081-1089.

WHO - WORLD HEALTH ORGANIZATION. 2017. Available at: http:/www.who.int/mediacentre/factsheets/2003/ fs $134 / \mathrm{en} /$.

WILSON EO. 1999. The Diversity of Life. New York: Harvard University Press, $424 \mathrm{p}$.

ZERAIK ML, QUEIROZ EF, MARCOURT L, CICLET O, CASTRO-GAMBOA I, SILVA DHS, CUENDET M, BOLZANI VS AND WOLFENDER JL. 2016. Antioxidants, quinone reductase inducers and acetylcholinesterase inhibitors from Spondias tuberose fruits. J Funct Foods 21: 396-405. 